\title{
DEVELOPING A MODEL OF HOTS QUESTIONS FOR READING NARRATIVE TEXT
}

\author{
Evelyn Simanjuntak \\ SMA Negeri 2 Jorong \\ evelynnnsimanjuntak@gmail.com
}

\begin{abstract}
In ESL classroom, teachers need qualified reading material together with some questions excercicesto fill students' need to train their higher order thinking. This opinion is in accordance with Miskiah $(2015,87)$. She said that the learning material plays a very important role in a learning process, it is the representation of teacher's explanation in the classroom. On the other side, learning material is one of the learning aid to achieve the core competency. It also helps teachers in learning process, helps students to learn one component systematically so that the student may be able to master a certain competency completely and integratedly. Moreover, learning material may be defined as series of facts, concept, foundation, procedures, and a devised generalisation specifically to make the learning process becomes easier (Abidin, 2012:33).This research analyses the effectiveness a product of HOTS questions for reading narrative text on IX grade students of SMPN 2 Jorong. the Procedure of instructionalmaterial development is aimed to make the material developed is suitable to the reader and the class condition.The research design applies 4D (four D model) Research and Development. According to Thiagarajan, (1974:6-9), this has 4 steps that is : defining, design, development, and disseminating. By the research the writer tries to dig studets critical thinking and they can be the creative students in the future.
\end{abstract}

Keywords: HOTS questions, reading, narrative text

\section{Introduction}

In recent years, a lot of emphasis has been given to the teaching of thinking skills in the ESL classroom. The Indonesian Constitution no 20 year 2003 article 3 aims at producing faithful, healthy, knowledgeable, smart, creative, self-supporting students and be democratic and responsible person. Based on the objective of the Indonesian government constitution, Higher Order Thinking skills (HOTS) assesments are introduced to schools for this purpose, to enable students to apply their knowledge in their real life, analyze it, evaluate it and think creatively.

HOTS assesments are also applied at schools in National Examination. They are inserted in form of questions that make the students think critically, analytically and smart. Poorly, based on the result of the National Examination, South Kalimantan gets lower National Examination scores compared with those of 2017. In 2017 the scores were 52.90 and they declined to 51.67 in 2018 with 1.23 percentage difference (https://www. kanalkalimantan.com, verified feb 23, 2019).

For solving the problem of decreasing scores of Junior High School students on National Examination and the students' analytic thinking, the researcher tries to make an intsructional material contains excersice questions that may be able to arise students' high order thinking skils. Students' high order thinking skill(HOTS) is defined in terms of transfer, critical thinking and, problem solving (Brookhart, 2010).

Jack C Richards and Willy A Reinandya (2002:38) said that teaching reading process needs 6 (six) levels of thinking process, that is level of knowledge, comprehension, application, analysis, synthesis, and evaluation. These level should combine together in the learning process. If the students only learn several levels, the students mind wouldn't grow creatively and think analitically. If the stimuly in the teaching reading process doen't cover one of the levels of thinking process it is predicted that that the students are not able to inspire the others to solve several problems they face.

Developing HOTSquestions for reading narrative text also supports the government policy on Curriculum 2013. It has 4 (four) aspects to explore that is the aspects of knowledge, skill, affective, and attitude. It also supports the Minister Regulation No 21 year 
of 2016. The regulation regulates the Contain Standards of the Midle and the Elementary Education. The regulation also writes thatthe students should master the core competition includes spiritual attitude, socially attitude, knowlegde, and skill competency.

By this research, hopefully, the design of HOTS questionsof narrative text material may improve the students HOTS level and creates faithful, creative, knowlegable, and selfsupporting students of Indonesia. It is expected also be inspireable writing for the other research about how to create and raise smart Indonesia students.

Product specification of the instructional material covers (1) the content of the material, (2) the material systematic, (3) The language feature, and (4) the material performance.

The content of the material specification is as follow:

A. The content is in accordance with the Basic Competence (KD) for the Junior High School grade IX That is Basic Compentence 3.7 and Basic Kompetence 4.7. Basic Competence 3.7 states that the students are supposed to be able to compare the social function, text structure, language feature of some narrative text both written and orally by giving and asking the information related to fairy tales, shortly and simple according to the context. Basic Competence 4.7 states that the students are supposed to be able To get the meaning contextually related to the social function, text structure, and language feature on the narrative text both written and orally, very short and simple related to fairy tales.

B. The content is related to the narrative text, the Material contains the narrative text and the questions based on the text discussed, learns the language feature of narrative text, hopefully the students are able to tell the answer of the questions and retell the story with their point of view creatively.

C. The objectives of the lesson are to make the students be able to learn the narrative with the language feautures, think critically and creatively, analyse the text, and appreciate the narrative text.

D. The examples of the narrative text is taken from student text book, printed media, and digital media.

E. Reading practice is done by reading aloud, answering the questions, knowing the language features, listening the story, and retelling the story with their own version.

F. Evaluation is done by evaluating student's reading ability, answering the question, knowledge of language features, and retelling the story with their own version.

Higher Order Thinking skills (HOTS) was introduced to schools for this purpose, to enable students to apply, analyse, evaluate and think creatively.HOTS is defined in terms of (1) transfer, (2) critical thinking and, (3) problem solving (Brookhart, 2010). In describing transfer, Brookhart (2010) states that students not only acquire knowledge and skills, but also the ability to apply the knowledge and skills to new situations. This applies to life outside of school where thinking is considered a series of transfer opportunities rather than a series of recalled assignments.

Norris and Ennis (1989) described critical thinking as referring to reasonable, reflective thinking to decide on what to believe or do. Students can therefore apply wise judgement or produce a reasoned critique.

Problem solving may be defined as a skill to find a solution to a problem that cannot be solved simply by memorizing (Collins, 2014). This includes the ability to remember 
information, learn with understanding, critically evaluate ideas, formulating creative alternatives, and communicating effectively. The relationship between reading skills and critical thinking has been highlighted as a field in cognitivepsychology.

Piaget (1952) presented three cognitive processes which are assimilation, accommodation, and equilibrium. Assimilation is explained as a continuous process that helps one to integrate new information with existing schemata. Accommodation is the process of developing or constructing new schemata because there is no prior schema to add on to or modify. Equilibrium is a balance between assimilation and accommodation. According to Rubin (1997), equilibrium process would enable a child to see similarities between the stimuli and assimilate them, and also determine when new schemata are needed for accommodation.

A number of researches support the idea that critical thinking and reading are interrelated (Beck, 1989; Ruggiero, 1984; Yu-hui et al., 2010). Critical thinking enables one to work out reading texts by generalizing and interpreting, analyzing according to prior or world knowledge and synthasising. However, the investigation is investigating of how teachers construct pedagogical content knowledge for teacing language skills by integrating HOTS in smp n 2 Jorong (Malini \& Sarjit, 2014).

Jack C Richards and Willy A Reinandya (2002:38) said that teaching reading process needs 6 (six) levels of thinking process, that is level of knowledge, comprehension, application, analysis, synthesis, and evaluation. These levels should combine together in the learning process. If the students only learn several levels, the students mind wouldn't grow creatively and think analitically. If the stimuly in the teaching reading process doen't cover the synthesis level it is predicted that the students are not able to inspire the others to solve several problems they face.

\section{Discussion}

to ease and make shorter the process of designing the product, the researcher limits the development just to six steps. Besides, the researcher also adapts the process with the needs of development.

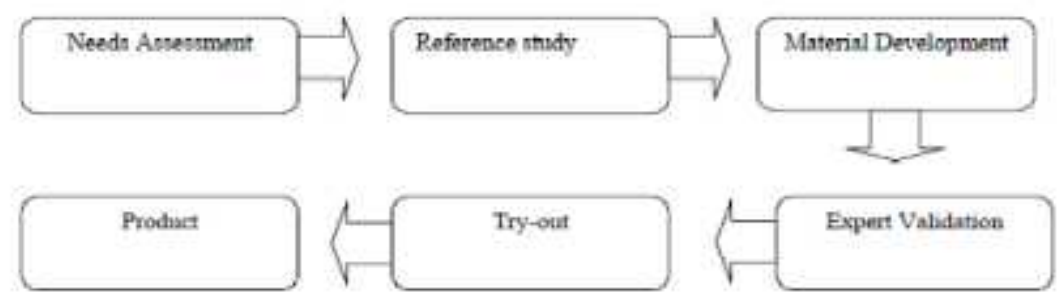

Figure 1. Design of Current Study (in Hermaniar 2013, adapted from Borg and Gall)

This studies the Material Development Expert Validation Try-out ProductIn developing the supplementary material for students of SMP N 2 Jorong, the model proposed by Borg and Gall is adapted. The model involves the following steps:needs assessment, reference study, material development, expert validation, tryout, and final product. 


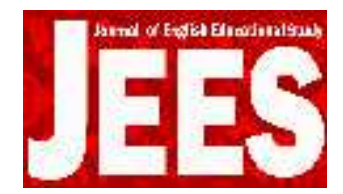

Journal of English Educational Study

Volume 1 Issue 2 November 2018 Page 77-81

E-ISSN: 2655-0776

Based on the observation it is seen the activity of the students in the classroom

Table 1. students activities in the classroom

\begin{tabular}{|c|c|c|c|c|}
\hline No & AKTIVITAS SISWA & $\begin{array}{l}\text { PRA } \\
\text { SIKLUS }\end{array}$ & $\begin{array}{c}\text { SIKLUS } \\
1\end{array}$ & $\begin{array}{c}\text { SIKLUS } \\
2\end{array}$ \\
\hline 1. & $\begin{array}{l}\text { Mental activities } \\
\text { (mernperhatikan penjelasan gunu) }\end{array}$ & $\begin{array}{l}15 \text { sisva } \\
(43 \%)\end{array}$ & $\begin{array}{c}25 \text { sswa } \\
71 \%)\end{array}$ & $\begin{array}{c}34 \text { sswa } \\
(97 \%)\end{array}$ \\
\hline 2. & $\begin{array}{l}\text { Writing activites } \\
\text { (mencatat'menulis) }\end{array}$ & $\begin{array}{l}17 \text { siswa } \\
(49 \%)\end{array}$ & $\begin{array}{c}30 \text { siswa } \\
(86 \%)\end{array}$ & $\begin{array}{l}33 \text { siswa } \\
\text { (94\%) }\end{array}$ \\
\hline 3. & $\begin{array}{l}\text { Oral acdivities } \\
\text { (bertanya) }\end{array}$ & $\begin{array}{c}15 \text { siswa } \\
\text { (43\%) }\end{array}$ & $\begin{array}{c}20 \text { sswa } \\
(57 \%)\end{array}$ & $\begin{array}{c}26 \text { siswa } \\
\text { (74\%) }\end{array}$ \\
\hline 4. & $\begin{array}{l}\text { Oral activities } \\
\text { (menjawab) }\end{array}$ & $\begin{array}{l}13 \text { siswa } \\
\text { (37\%) }\end{array}$ & $\begin{array}{c}25 \text { siswa } \\
(72 \%)\end{array}$ & $\begin{array}{l}32 \text { siswa } \\
(91 \%)\end{array}$ \\
\hline 5. & $\begin{array}{l}\text { Oral actuities } \\
\text { (malakukan diskusi kelompok) }\end{array}$ & $\begin{array}{c}15 \text { siswa } \\
(43 \%)\end{array}$ & $\begin{array}{c}25 \text { siswa } \\
(71 \%)\end{array}$ & $\begin{array}{l}35 \text { siswa } \\
(100 \%)\end{array}$ \\
\hline \multicolumn{2}{|c|}{ Rata - rata } & 15 siswa & 25 sisva & 32 siswa \\
\hline \multicolumn{2}{|c|}{ Persentase } & $4285 \%$ & $71,42 \%$ & $91,42 \%$ \\
\hline
\end{tabular}

\section{A. Hasil Belajar Siswa}

Based on the data taken from the test, it can be seen that that the scores of the students are increasing. The apllying of HOTS questions is repaired and applied in cycle2 After doing cycle 2 the students scores are increasing significantly.

Table 2. Students test results on applying HOTS questions of narrative text in grade IX C SMP Negeri 2 Jorong.

\begin{tabular}{|c|c|c|c|c|}
\hline No & AKTIVITAS SISWM & $\begin{array}{l}\text { PRA } \\
\text { SIKLUS }\end{array}$ & SIRLUS & $\frac{\text { SIKLUS }}{2}$ \\
\hline 1. & $\begin{array}{l}\text { Mental activities } \\
\text { (memperhatikan penjelasan gumu) }\end{array}$ & $\begin{array}{l}15 \text { siswa } \\
(435)\end{array}$ & $\begin{array}{l}25 \text { siswa } \\
(719 \%)\end{array}$ & $\begin{array}{l}34 \text { siswa } \\
(97 \%)\end{array}$ \\
\hline 2. & $\begin{array}{l}\text { Whing actiwhes } \\
\text { (mencatatimenulis) }\end{array}$ & $\begin{array}{l}17 \text { siswa } \\
(49 \%)\end{array}$ & $\begin{array}{l}30 \text { siswa } \\
\text { (a6\%) }\end{array}$ & $\begin{array}{l}33 \text { siswa } \\
(94 \% 6)\end{array}$ \\
\hline 3. & $\begin{array}{l}\text { Oral activities } \\
\text { (beartarya) }\end{array}$ & $\begin{array}{c}15 \text { siswa } \\
(43 \times)\end{array}$ & $\begin{array}{l}20 \text { siswa } \\
(5796)\end{array}$ & $\begin{array}{c}25 \text { siswa } \\
(746)\end{array}$ \\
\hline 4. & $\begin{array}{l}\text { Oral acthimes } \\
\text { (imenjewab) }\end{array}$ & $\begin{array}{c}13 \text { siswa } \\
{[37 \text { st }}\end{array}$ & $\begin{array}{c}25 \text { siswa } \\
(72 \%)\end{array}$ & $\begin{array}{l}32 \text { siswa } \\
(91 \%)\end{array}$ \\
\hline 5. & $\begin{array}{l}\text { Orai acthoties } \\
\text { (melakukan diskusi kelompok) }\end{array}$ & $\begin{array}{c}15 \text { siswa } \\
(43 \%)\end{array}$ & $\begin{array}{c}25 \text { siswa } \\
(7+\%)\end{array}$ & $\begin{array}{l}35 \text { siswa } \\
(100 \%)\end{array}$ \\
\hline \multirow{2}{*}{\multicolumn{2}{|c|}{ Rata - rata }} & 15 siswa & 25 siswa & 32 siswa \\
\hline & & $42,85 \%$ & 71.425 & $91.42 \%$ \\
\hline
\end{tabular}

Briefly, material is important element during the learning process. Appropriate material will catch students' interest that motivate them to know what they could get today in learning. Students would expect they will learn something, know new information,

\section{Conclusion and Suggestion}

Briefly, material is important element during the learning process. Appropriate material will catch students' interest that motivate them to know what they could get today in learning. Students would expect they will learn something new, know new information, and can think creatively based on the story they learnt. We cannot deny that students nowadays are getting bored with the old stuff or maybe some teachers are not using material optimally. 
This would cause lack of motivation and lead to boredom. Teachers are models for students an learning process. Teachers should be more creative, unique, and can create the comfort environment in the class. Teaching is not only giving tons of exercises but also creating activities that $\mathrm{w}$ more interested but enhancing students' comprehension of what they are studied.

\section{REFERENCIES}

Anita Lie. 2003. Cooperatif Learning: Mempraktekkan Cooperatif Learning di Ruang-Ruang Kelas. Jakarta: Gramedia.

Aris shoimin. (2014). Model Pembelajaran Inovatif Dalam Kurikulum 2013. Yokyakarta: AR-ruz media.

Bachtiar Bima,M. Andreas Winardi, Siti Nurmalina, S. 2005. Let's Talk kelas 9. Bandung: Pakar Raya.

Burhan Nurgiyantoro. 2001. Penilaian dalan Pengajaran Bahasa dan Sastra. Yoggyakarta: BPFE

Ibrahim, M. 2000. Pembelajaran Kooperatif. University Press. Surabaya.

Kridalaksana, Harimurti. 2008. Kamus Linguistik. Jakarta: Gramedia Pustaka Utama.

Richard J.C dan Renandya, W.A. 2002. Methodology In Language Teaching An Anthology Of Current Practice, Cambridge University Press

Depdikbud. 2003. Kamus Besar Bahasa Indonesia. Jakarta : Balai Pustaka 2003. Undang-Undang No. 20 Tahun 2003, tentang Sistem Pendidikan Nasional. Jakarta : Depdiknas. 